\title{
ARIOWIE I TURAŃCZYCY. POGLĄDY FRANCISZKA H. DUCHIŃSKIEGO NA TEMAT RASY I CYWILIZACJI
}

\author{
ARYANS AND TURANIANS. \\ FRANCISZEK H. DUCHIŃSKI'S VIEWS ON RACE \\ AND CIVILIZATION
}

\begin{abstract}
The article deals with a theory of non-Slavic origins of Russians. This theory was authored by Franciszek Duchinski (1816-1893) who claimed that civilizational specifity of Russians stems from their racial origin that is different from the origin of the remaining European nations. He believed that because of this fact, two opposing civilizations emerged: the eastern civilization created by the Mongolian root, with a lack of rule of law and domination of despotism, and the western civilization existing among the Indoeuropean peoples who respected freedom and human dignity. Duchinski was convinced that the two civilization differed one from another most of all due to several external and mental factors instead of biological discrepancies. He did not evaluate races and civilizations as better or worse, and he did not giva a definion of the notion of race. This unprecise attitude was characteristic of the $19^{\text {th }}$ century writings. Such notions as "race," "nation," "tribe," or "clan," were used interchangeably. Moreover, racial hierarchy was not considered as something improper.

Duchinski's views on the Asian despotism on the whole agreed with those abiding in the Polish writings in the $19^{\text {th }}$ century, with dominating opinions that Russia and Europe represented different civilizations and were in a permanent antagonism. Duchinski's aim was to warn Western European community that East is a threat to the West and he wanted to demonstrate that Poland had a role to play for the Latin Christianity.
\end{abstract}

\author{
KATARZYNA WRZESINSKA, \\ Instytut Slawistyki PAN. \\ Correspondence: \\ kasiawrzesinska62@gmail.com
}

This is an Open Access article distributed under the terms of the Creative Commons Attribution 3.0 PL License (creativecommons.org/licenses/by/3.0/pl/), which permits redistribution, commercial and non-commercial, provided that the article is properly cited. (C) The Author(s) 2015.

Publisher: Institute of Slavic Studies PAS [Wydawca: Instytut Slawistyki PAN] 
His conclusions about the antynomy of civilizations are still valid even though today we tend to deny that race and civilization are interconnected. Now civilizational identity is seen first of all in a variety of different values, beliefs, institutions and social structures. Thus, one should agree with Duchinski that civilizations are indeed different but we still should avoid to evaluate them as better or worse.

Key words: race; eastern civilization; Turanians; Russians; western civilization; Aryans; Slavic Word; clash of civilizations

\section{Streszczenie}

Tekst jest poświęcony teorii niesłowiańskiego pochodzenia Rosjan. Jej autor, Franciszek H. Duchiński (1816-1893), uzasadniał odmienność cywilizacyjną Rosjan ich innym od pozostałych ludów Europy pochodzeniem rasowym. Ono, jak uważat, zadecydowało o powstaniu funkcjonujących w opozycji dwóch cywilizacji: wschodniej, stworzonej poprzez pierwiastek mongolski, gdzie dominowało bezprawie i despotyzm, oraz zachodniej, powstałej jako wytwór ludów indoeuropejskich, które respektowały wolność i godność człowieka. Duchiński uzasadniał różnice między nimi w większym stopniu czynnikami zewnętrznymi i mentalnymi niż biologicznymi. Nie wartościował ras i cywilizacji, a pojęcia "rasa" nie definiowat. Brak ścisłości w tym względzie był charakterystyczny dla XIX-wiecznego piśmiennictwa. Często stosowano zamiennie pojęcia "rasa”, "naród”, „plemię", „szczep". Nie uważano też za naganne hierarchizowania ras.

Opinie Duchińskiego na temat azjatyckiej despotii nie odbiegały od powszechnie przyjętych w piśmiennictwie polskim XIX w. Dominujący w nim wątek stanowiło przekonanie o odmienności cywilizacyjnej Rosji i Europy i o trwałym pomiędzy nimi antagonizmie. Działalność Duchińskiego miała służyć uświadomieniu opinii zachodnioeuropejskiej zagrożenia jakie płynęło dla Europy ze strony cywilizacji wschodniej oraz roli Polski na przedmurzu chrześcijaństwa łacińskiego.

Spostrzeżenia na temat antynomii wspomnianych cywilizacji są i dziś aktualne. Współcześni badacze problemu przeczą rzecz jasna związkom pomiędzy rasą i cywilizacją. Kładą za to nacisk na różnice w sferze wartości, wierzeń, instytucji i struktur społecznych, które decydują o tożsamości cywilizacyjnej. O ile więc można nie godzić się z argumentacją Duchińskiego, to w sferze wniosków należy autorowi przyznać rację i nie wartościując cywilizacji uznać je za odmienne.

Stowa klu c zo we: rasa; cywilizacja wschodnia; Turańczycy; Rosjanie; cywilizacja zachodnia; Ariowie; Słowiańszczyzna; zderzenie cywilizacji 
Z powodu krzywd wyrządzonych przez nazizm i faszyzm historia ras nie cieszy się zbytnim szacunkiem wśród współczesnych badaczy (...). Nie da się jednak zaprzeczyć, że w przeszłości teorie biologiczne odegrały istotną rolę w debatach na temat rozwoju historycznego (...).

Davies, 2014, s. 342

M yślenie w kategoriach „swój” i „obcy” towarzyszyło ludzkości od zarania dziejów. Ludzie różnili się bowiem między sobą pochodzeniem, wyglądem, obyczajowością, wyznawanym systemem wartości, religią i językiem, czyli tożsamością kulturową. Ona to stanowiła z czasem najsilniejsze oparcie każdej wspólnoty narodowej. "Obcy" stawał się więc częstokroć wrogiem, przed którym należało bronić swojej tożsamości (Huntington, 2000, ss. 13-22). W XIX-wiecznych rozważaniach historiozoficznych na powyższe rozróżnienie nakładało się ujęcie dziejów ludzkości poprzez pryzmat walki dobra ze złem - boga światła, mądrości i prawdy zbogiem ciemności, kłamstwa i zniszczenia W piśmiennictwie polskim sięgano czasem do nazewnictwa staroirańskiego, pisząc o odwiecznych zmaganiach Ormuzda z Arymanem (Staszic, 1959a, ss. 21-60, 1959b, ss. 357-380; Krasiński, 1912, s. 118; Pawlikowski, 1952). W kontekście społeczno-politycznego ukształtowania świata wielu XIX-wiecznym polskim twórcom rysował się jego podział na mentalnie odrębne części (uosabiające dobro i zło), toczące ze sobą walkę. Jako jej podłoże istotna stawała się nie tylko tożsamość kulturowa, ale także cywilizacyjna. Poprzez poczucie przynależności do cywilizacji zachodniej identyfikujący się z polskością wpisywali się w dychotomiczną wizję świata podzielonego na Wschód i Zachód (Opacki, 2000, ss. 239-252; Wierzbicki, 2009, ss. 13-32). Nieco inaczej postrzegali tę kwestię XIX-wieczni uczeni Edward B. Tylor i Lewis H. Morgan. Choć prezentowali oni powszechne wówczas przekonanie o uniwersalnym charakterze cywilizacji europejskiej (uznawanej za wzorzec dla wszystkich społeczeństw czy ludów), to jednak nie stawiali jej w opozycji do Wschodu, czyli cywilizacji azjatyckiej, rosyjskiej, ale całej reszty świata (Krzemień, 1971, s. 8). Dlatego też, jak sądzono na Zachodzie, europeizująca się od czasów Piotra I Wielkiego Rosja, której nieco się bano, ale i podziwiano zarazem, mogła być równoprawnym i wiarygodnym partnerem politycznym i gospodarczym (A. Nowak, 1998, ss. 74-75).

Dla niniejszego artykułu ważne jest stwierdzenie, że Polacy, zwłaszcza w drugiej połowie XIX w., szukali różnych dróg, by uzmysłowić opinii zachodnioeuropejskiej nie tylko całkowitą odmienność Rosji od państw zachodu Europy, ale też jej ukrytą wobec nich wrogość. Tu dochodzimy do osoby Franciszka Henryka Duchińskiego (1816-1893), działacza Wielkiej Emigracji, który poświęcił się udowodnieniu niesłowiańskiego pochodzenia Rosjan, w kategorii rasy upatrując źródeł odmienności między cywilizacjami Wschodu i Zachodu. Jego twórczość stanowi przykład na to, że poczucie klęski wywołane utratą niepodległości stworzyło podatny grunt dla pojawienia się takich koncepcji historiozoficznych, które mogłyby stanowić wyjaśnienie powodów unicestwienia państwowości polskiej, a jednocześnie uzasadnienie istotnej roli Polski w perspektywie rozwoju sytuacji politycznej Europy, Rosji i Słowiańszczyzny. Wizję Duchińskiego należy umieścić w bardzo bogatym nurcie myśli polskiej, która upowszechniała i utrwalała przekonanie o antagonizmie dwóch cywilizacji - europejskiej i azjatyckiej, o sprzeczności między wolnością i despotyzmem, prawem i bezprawiem (A. Nowak, 1999; deLazari, 2006). 
Warto poświęcić kilka stów przybliżeniu XIX-wiecznej terminologii stosowanej w polskiej nauce i publicystyce. Terminowi "rasa” nadawano różnorodne i pojemne znaczenia. Rzecz jasna pojawia się on w rozważaniach w kontekście biologii porównawczej człowieka, czyli antropologii fizycznej, dziale tej nauki historycznie najstarszym (Bielicki, Krupiński, \&Strzałko, 1987). Wówczas rozumienie pojęcia „rasa” nie nasuwa wątpliwości. Na gruncie polskim przyswajano i upowszechniano zdobycze nauki światowej w tym względzie. Znane i dyskutowane były na przykład różnorodne klasyfikacje ras, uwzględniające cechy fizyczne (kolor skóry, rodzaj włosów, kształt czaszki), których dokonali w XVIII i XIX w. m. in. J.F. Blumenbach, G. Cuvier, P. Broca czy A. Retzius. Wielu badaczy przypisywało rasom nie tylko właściwe dla nich cechy fizyczne, ale także psychiczne. W dociekaniach nad zróżnicowaniem społeczeństw, jeśli nie brano pod uwage czynników wpływających na ich ewolucję, wysuwano hipotezę o nierówności ras ludzkich. Najszerzej objaśnit ją Artur Gobineau (Sobeski, 1925, ss. 28-78). Wątki zbliżone do jego filozofii społecznej można także znaleźć u ewolucjonistów, L. H. Morgana, H. Spencera, A. C. Haddona i J.G. Frazera, którzy różnicowali ludy (rasy) na "wyższe” i "niższe” podług ich przyrodzonych i dziedzicznych, jak sądzili, zdolności. Jak wskazuje J. Szacki, w wymienionych przypadkach termin "rasa" również bywał nie do końca jasny (Szacki, 1981, ss. 341 342; Szczurkiewicz, 1969, ss. 131-192). Zarówno Jean B. Lamarc jak i Charles Darwin uwzględniali w swoich teoriach ewolucji tezę o dziedziczności cech nabytych (Popowicz, 2009, ss. 99-100). Koncepcję tę ostatecznie obalił rozwój genetyki. Polski uczony Feliks Koneczny, podsumowując XIX-wieczne opinie na temat rasy, stwierdzał, że to pojęcie łączono z „pokrewieństwem i dziedziczną stałością” (inaczej ciągłością dziedziczenia). Jednocześnie obalono pogląd o istnieniu "rasy czystej" jako grupy charakteryzującej się jednością krwi. Skłaniano się raczej do traktowania rasy jako jedności kulturowej (Koneczny, 1935, s. 168; Krzywicki, 1893/1969, s. 26).

W polskiej myśli tego okresu, u zarania rozwoju antropologii, w dociekaniach nad istotą człowieka i nad źródłami jej niejednorodności akceptowano syntetyczne spojrzenie na zagadnienie rasy. Taki kierunek dociekaniom niewątpliwie nadał fakt, iż refleksje $w$ tym względzie przeprowadzali ludzie o różnorodnym wykształceniu, częstokroć będący samoukami jeśli chodzi o zgłębianą dziedzinę - jak właśnie m.in. Franciszek H. Duchiński. Często przyczyną podejmowania analiz stawał się czynnik polityczny. Prowadzito to do zbaczania na manowce nauki, w stronę wyobrażeń, mitów i stereotypów. Tak czy inaczej, rase definiowano jako konglomerat dziedzicznych cech psychicznych i fizycznych danej grupy, wyrosłych na podłożu etniczno-kulturowym w wyniku wielowiekowego pożycia na danym terytorium. Nie przykładano jednak wówczas większej wagi do uściślania tego pojęcia'. Można by rzec, że kategoria rasy służyła wskazywaniu odmienności między ludźmi. Jeśli dokonywano wartościowania ras, pewnej ich hierarchizacji, to najczęściej miernikiem stawał się porządek życia społecznego, zbiór idei, praw i zasad istotny dla danej rasy. W publicystyce polskiej XIX w. konkretnej rasie (w znaczeniu zbiorowości, populacji) przypisywano zazwyczaj zespół charakteryzujących ją właściwości, kładąc akcent na wspólnotę szeroko pojętej kultury. Dlatego też w obrębie rasy ludzie byli sobie duchowo bliscy, fizycznie podobni nie tylko karnacją czy kolorem włosów, ale i ubiorem, cenili pewien -......

Potwierdzają ten fakt XIX-wieczne stowniki, w których „rasa” to "gatunek letkiej materyjki wetnianej” (Linde, 1859, s. 28) i w interesującym tu kontekście: „plemię, pochodzenie, pokolenie” (Stownik Języka Polskiego, 1861, s. 1341). Encyklopedie zaś zamieszczają różnorodne klasyfikacje ras podług cech fizycznych ludzi (Encyklopedia Powszechna, 1865, s. 951). 
zbiór wartości, respektowali te same zasady. Takie ujęcie byłoby niewątpliwie zgodne ze spojrzeniem Ludwika Krzywickiego, dla którego "duch rasy" nie był kategorią biologiczną, lecz wynikiem przeszłości historycznej, czymś w rodzaju „potencji kulturalnej” (Krzywicki, 1902/1969, ss. 578-588; Bielicki i in., 1987, s. 6)². Podobnie Ludwik Gumplowicz stwierdzat, że rasa ma swe podłoże w elementach duchowych, wobec których jedność krwi stanowi czynnik wtórny (Gumplowicz, 1887; Gella, 1966, ss. 86-88; Szacki, 1981,ss. 409411). W piśmiennictwie europejskim (np. Le Bon, 1897/1999), w tym i w prasie polskiej pod zaborami często stosowano zamiennie pojęcia "rasa”, „naród” i „plemię". Wynikało to w części z faktu, iż nie przykładano wagi do ich precyzowania, w części z różnorodności samych definicji. W przypadku polskim zaś cenzura W zaborze rosyjskim określenie "naród polski" eliminowała.

Używano terminu „rasa”, opisując pochodzenie ludów i różnice między nimi. Rozróżniano rasy romańską, słowiańską i germańską, a wszystkie one współtworzyły rasę indoeuropejską (utożsamiono pierwotną wspólnotę językową z domniemaną biologiczną). Na jej z kolei określenie przyjęto również termin „aryjska” i wedle tej nomenklatury Polacy byli Aryjczykami³. W XIX w. i w pierwszej połowie wieku XX rozważania na temat etnogenezy Stowian miały konotacje polityczne. Koncepcja autochtoniczna, wedle której pierwotne siedziby Słowian leżały w centrum Europy między Odrą a Dnieprem, z jednej strony miała potwierdzać polskie prawa do ziem zagarniętych przez Niemcy, z drugiej zaś czyniła je odwiecznymi siedzibami Polaków, które przemocą zajęli Rosjanie - lud jeśli nawet pierwotnie słowiański, to silnie podległy w przeszłości wpływom mongolskim. Zwany był on przez wielu także turańskim. Publicystyka polska tego okresu, a nawet nauka, operowała często stereotypowymi negatywnymi obrazami nacji czy ras wrogich polskości. Starano się przy tym udowodnić wyższość Słowian - Polaków (pojmowaną zresztą różnorodnie: jako lepsze pochodzenie, „rasową czystość” - cokolwiek określenie to miałoby znaczyć, zalety mentalności, zasługi historyczne, predestynację do pełnienia misji odnowy świata), ponieważ sądzono, że to właśnie ona daje i potwierdza prawa do zasiedlanych ziem. Również w ówczesnych Czechach widoczna była tendencja do nobilitacji własnego narodu i jego dziejów, podobnie jak w Polsce wynikająca z przyczyn politycznych (Strzelczyk, 2003, s. 790). Trzeba jednak wskazać, że piśmiennictwo XIXwieczne odzwierciedlało ówczesny stan wiedzy i wyobrażeń na temat dziejów Słowiańszczyzny. Uznani myśliciele i twórcy polscy jak Stanisław Staszic, Joachim Lelewel, Kazimierz Brodziński czy Adam Mickiewicz idealizowali Słowiańszczyznę. Zgodnie z Herderowską wizją, po erach romańskiej i germańskiej przyjść miała słowiańska, odnawiając życie dzięki młodszości cywilizacyjnej Słowian, którzy jak dotąd nie odegrali w dziejach ludzkości znaczącej roli (Michalski, 2013, ss. 37-68; Wierzbicki, 1999, ss. 145-156, 2012, ss. 66-69). Co istotne, w myśli polskiej ze słowiańskiego szczepu często wyłączano Rosję, jako twór odmienny, bo "skażony" pierwiastkami bizantyjskim i mongolskim, a antagonizm polsko-rosyjski przedstawiano na szerokim tle walki cywilizowanej Europy z barbarzyńskim Wschodem (Wierzbicki, 1984, ss. 108-116; Karpiński 1994, ss. 160-180). Z kolei Rosjanie wyłączali ze Słowiańszczyzny Polskę, „skażoną” latynizmem i okcydentalizmem (Wierzbicki, 2012, s. 70).

\section{- ...}

Pojęcie „potencja kulturalna” przytaczam za Janem Ludwikiem Popławskim (W. B., 1900, s. 413).

Mit aryjski pojawił się z końcem XVIII w. w dziedzinie językoznawstwa porównawczego. Wówczas odkryto rodzinę języków indoeuropejskich. Termin "Aryjczyk" wprowadził Thomas Young (1816), a następnie Friedrich Schlegel (1819), akcentując pochodzenie ludności Europy od starożytnych Hindusów. Był on używany jako synonim „Indo-Europejczyka” i "Indo-Germanina” (Popowicz, 2009, ss. 77-78). 
W meandrach ówczesnej polskiej myśli na temat Rosji w kontekście dziejów Polski i Europy zaznaczył się wspomniany etnograf, historyk, działacz emigracyjny Franciszek H. Duchiński. Poświęcit się on badaniom nad specyfiką rasową Rosjan, starając się udowodnić ich odmienność od pozostałych ludów europejskich (pierwsze wydanie trzytomowego dzieła na ten temat ujrzało światło dzienne w Paryżu w latach 1858-1861). Rasa u Duchińskiego to ostatecznie pojęcie współtworzone przez wiele czynników, nie tylko biologicznych, ale także geograficznych, duchowych i kulturowych. Duchiński opowiadał się za „pierwotną jednością rodu ludzkiego”, czyli koncepcją monogenezy. W tym więc ujęciu pochodzenie zarówno Rosjan jak i innych ludów byłoby tożsame. Obserwowane przez uczonych różnice pomiędzy ludźmi uznawał za wyrosłe z biegiem czasu pod wpływem czynników zewnętrznych (a więc nie biologicznych). One to dały podstawę do tworzenia wielorakich podziałów podług cech zwracających uwagę badaczy (jak na przykład kolor skóry, forma czaszki) ${ }^{4}$. Jednocześnie, jak uważał, wspomniane różnice stworzyły przesłanki dla rozwoju błędnych teorii o niejednorodności pochodzenia rodu ludzkiego (koncepcja poligenezy), a co z tego wynikało - o przyrodzonych nierównościach między ludźmi. Duchiński wskazywał na Amerykę jako źródło pochodzenia takich koncepcji. Miały one służyć usprawiedliwieniu niewolnictwa. Dostrzegał, że teoria nierówności ras pojawiła się także w Europie i wypływała z "nędznych pobudek” oraz chęci "popisywania się niby to nowymi wynalazkami". Duchiński znał prace Josepha Arthura de Gobineau Essai sur l'inégalitè des raceshumaines wydaną w latach 1853-1855 i odnosit się do niej krytycznie (Duchiński, 1904, s. 13). W pewnym stopniu jednakże uznawał teorię nierówności ras, ale rozumianych jako populacje różniące się tożsamością kulturową i cywilizacyjną. Przystosował niektóre spostrzeżenia Gobineau dla własnych potrzeb - powołał się m.in. na francuskiego myśliciela, gdy pisał o „nieczystości” języka rosyjskiego (Duchiński, 1902, s. 105), ale nie skorzystał już, rzecz jasna, z tych partii tekstu, w których Słowianie zostali uznani za lud niższy w stosunku do Germanów.

Podobnie jak inni XIX-wieczni badacze opierający się na tradycji biblijnej, podział ludzkości na rasy Duchiński traktował jako dzieło Boże. Józef Szujski wywodził różnorodność ras od synów Noego (Szujski, 1867, s. 23), Duchiński wskazywał też jako jej źródło historię Wieży Babel. Dalej zaś pisał:

Przykro wspomnieć chrześcijaninowi, że są na świecie rasy ludzi, to jest, że wszyscy ludzie nie są jednakowo usposobieni do wyrobienia w sobie jednakowych we wszystkich punktach zasad w życiu dziejowem. (...) Wszystkie rasy są powołane do zbawienia wiecznego, ale w życiu codziennem, w życiu dziejowem narody mają rozmaite środki do życia, rozmaite charaktery życia. (...) jeżeli trwają [one - K. W.] od lat dwóch tysięcy i więcej, zowiemy [je - K. W.] stałymi charakterami cywilizacji tych narodów lub ras (Duchiński, 1901, s. 141).

W powyższym kontekście Duchiński wspominał o rasach białej, czarnej i żółtej. Co istotne, wskazywał, że różnią się one nie tylko kolorem skóry i budową fizyczną, ale też "skłonnościami umysłowymi i moralnymi", które de facto odgrywają w dziejach rolę decydującą (Duchiński, 1902, s. 120). Podobnie postrzegał problem różnic między "grupami

\section{......}

4 Autor przytacza klasyfikację antropologiczną wg Johanna F. Blumenbacha (1752-1840), uczonego niemieckiego uznawanego często za ojca antropologii. Popularna była ona jeszcze w początkach XX w. Blumenbach wyróżniał następujące rasy: kaukaską (białą), mongolską (żółtą), etiopską (czarną; Duchiński nazywał ją egipską), amerykańską (czerwoną) i malajską (brunatną; przez Duchińskiego nazwaną oliwkową), (Duchiński, 1904, s. 14). 
naturalnymi", jak nazywał rasy, Szujski. Po pobieżnym wskazaniu na różnorodne klasyfikacje stwierdzał, że "gdyby więcej (...) zajmowano się objawami myśli tych ras, zamiast ich (...) czaszkami, nie wątpię, że wedle miary duchowej daleko trafniej by je rozgatunkowano" (Szujski, 1867, ss. 1-2).

\section{ROSJANIE TO NIE SLOWIANIE}

Duchiński uznawał podział rodu ludzkiego w obrębie rasy białej na trzy "szczepy": aryjski (indoeuropejski lub indogermański, a jeszcze inaczej: wenedyjsko-europejski), z którego wywodził cztery gałęzie, mianowicie romańską (łacińską), słowiańską (lechicką, wenedyjską), germańsko-skandynawską oraz galską (celtycką); uralski (turański), gdzie wyodrębnił gałąź Finów (lub Czudów), Mongołów i Turków, zaliczając do niej Rosjan; semitycki, obejmujący Żydów i Arabów. Uważał, że ludy indoeuropejskie już w pierwotnych swoich siedzibach, w Azji (według tradycji biblijnej), rozdzieliły się na wymienione wyżej gałęzie. Termin "Ariowie" i od niego pochodne uznawał za najbardziej właściwe dla indoeuropejczyków, wskazywały bowiem na pokrewieństwo ze starożytnymi Ariami. Sama nazwa tego ludu określała go jako "szlachetnie urodzonych".

Cechą, która wedle Duchińskiego zasadniczo różniła „szczepy” rasy białej, był prowadzony przez nie tryb życia - u indoeuropejczyków rolniczy i osiadły, u ludów uralsko-semityckich zaś „koczowniczy”, kupiecko-pasterski. Dla pierwszej grupy uważał Słowian za typowy lud o "cywilizacji rolniczej”, szczególnie Polaków znad Wisły i Dniepru; dla drugiej, turańskiego pochodzenia - Moskali, którzy choć trudnili się i rolnictwem to „(...) z musu, a nie z przyjemnością, jak Słowianie". Rodzaj obranego trybu życia miał decydujące znaczenie dla kształtowania się społeczności ludzkich, szczególnie ich mentalności. Poprzez termin „cywilizacja” Duchiński rozumiał „rozwój społeczny w pojmowaniu prawdy i piękna". Objawiała się ona w religii, „zatrudnieniach” (prowadzonym trybie życia), w podziale społecznym na stany, w języku i literaturze (Duchiński, 1901, ss. 26-27). Duchiński sądził, że umiłowanie rolnictwa i przywiązanie do ziemi ojczystej sprzyjały wyrobieniu pojęcia wartości prawa (stąd konstytucyjne formy rządów u ludów indoeuropejskich), własności ziemskiej, poszanowania wolności i godności ludzkiej. Formą życia społecznego charakterystyczną dla ludów aryjskich był federalizm, rozumiany jako dobrowolne połączenie wolnych z wolnymi. Natomiast tam, gdzie panował żywioł kupiecko-pasterski, praworządność była słabo rozwinięta, dominowało przywiązanie „(...) do osób, niż do ziemi, niż do prawa". Powstały więc warunki sprzyjające rozwojowi samodzierżawia jako formy rządu gwarantującej bezpieczeństwo. Wobec władcy wszyscy byli równi, ślepo mu posłuszni, jak niewolnicy. Tu tkwiło źródło tak charakterystycznej dla ludów turańskich, bierności połączonej z fanatyzmem. Dlatego też u Moskali carowi oddawano cześć niemalże boską (Duchiński, 1901, ss. 142-146, 1902, ss. 120-121, 1904, ss. 4, 14-18). Widzimy więc, że u Duchińskiego rasa biała dzieli się de facto na dwie grupy, a podział ten oparty jest na skłonnościach zarówno fizycznych jak i psychicznych.

W zastosowaniu tych zasad do całego rodu ludzkiego pokazało się, że część jego jedna więcej wyrabia wolności i dla niej bezpieczeństwo jest drugorzędnym tylko względem, druga zaś część ma za główny cel bezpieczeństwo, a wolność uważa jako rzecz drugorzędną. Przy takiem porównaniu widoczne jeszcze, że u narodów, które mają za cel główny wolność, przeważa żywioł rolniczy, ze wszystkiemi jego objawami.

Ludy aryjskie stanowią grupę, która ma na celu uprawę wolności; ludy turańskie zaś mają na celu uprawę bezpieczeństwa (Duchiński, 1904, s. 15). 
Na powyższe odmienności nałożyło się i dodatkowo je utrwaliło „wychowanie łacińsko-germańskie” [inaczej „europeizm” - K. W.], jakiemu podlegały ludy aryjskie. Wytworzona w ten sposób jedność „(...) okazuje się i w dziejach ich religijnych i politycznych, i w dziejach ich języka i literatury, i w dziejach ich cywilizacji, w najobszerniejszym znaczeniu tego wyrazu. Moskale wychodzą z harmonii Stowian we wszystkich tych punktach" (Duchiński, 1901, s. 146).Od zarania dziejów toczyła się więc walka pomiędzy rolniczym ludem Ariów a koczowniczymi Turanami (których siedziby rozciągały się na szerokich stepach na północ od ziem aryjskich). Ich nienawiść i brutalność, spojona organizacją wojskową, przegrywała w konfrontacji - jak pisał Duchiński - z inteligencją Ariów. Tego rodzaju przewaga uczyniła ich „panami ucywilizowanego świata”. Gdyby nie ten fakt,

(...) czyżby Arye zdołali oprzeć się tym wiekowym zapasom, rozpoczętym jeszcze w przeddziejowych czasach, a toczącym do dziś dnia z jednaką zaciętością. Gdyby nie ta przewaga, czyby Lechici, owi ostatni z Aryów przybysze do Europy, jak świadczy samo geograficzne ich położenie, umieli przez tyle wieków dźwigać na barkach swoich tę powódź turańską, tak groźną cywilizacji, którą ojcowie nasi tak długo odpierali tarczą dzielnego ramienia. Skruszyło się w końcu to ramię pod przemocą Turanów, lecz serce Polski bije dotąd silnem tętnem, a krew jej synów dziś jeszcze świadczy, że nie przepomniała wiekowego posłannictwa (Duchiński, 1904, s. 19).

Wspomniane zmagania zrodziły się z dwóch odmiennych wizji świata i człowieka, z dwóch sprzecznych ze sobą dążności. Turanowie - Moskale w wolności aryjskiej widzieli jedynie słabość (która w istocie była siłą) i w imię na swój sposób pojmowanej moralności zmagali się z moralnością, której nie rozumieli. Carowie moskiewscy - jako pomazańcy Boży - przekonani byli o swojej specjalnej misji „utrzymania świata w karbach porządku i bezpieczeństwa", co w istocie znaczyło niewolę (Duchiński, 1904, ss. 19-20). Skrystalizowana odmienność w sensie mentalnym i kulturowym stanowiła o wrogości Rosjan wobec Polaków, a także innych ludów europejskich. Duchiński, jakkolwiek uważał, że każdy lud zgodnie z wolą bożą inną drogą dąży do zbawienia i świętości, to jednak podkreślał, że w ciągu dziejów ( „już w czasach najodleglejszej starożytności”) dwa szczepy aryjski i turański znajdowały się w stałym antagonizmie, jako dwa przeciwne żywioły, przeciwne "charaktery cywilizacji” (Duchiński, 1902, ss. 25-36, 122).

Przekonanie o obcości cywilizacyjnej Rosjan nie stanowiło nowości w polskim piśmiennictwie. Jej źródeł dopatrywano jednak we wpływach Bizancjum oraz najazdach mongolskich z XIII w. Duchiński natomiast sądzit, iż one tylko utrwaliły odmienność rasową Moskali będących pierwotnie ludem pochodzenia mongolskiego. Ich rzekoma słowiańskość pojawiła się, jak pisał, dopiero wraz z przyjęciem i rozpowszechnieniem się chrześcijaństwa (Duchiński, 1901, ss. 126-129, 1902, ss. 116-119, 223, 227-243, 1904, ss. 81-82). Istotnym składnikiem teorii Duchińskiego było stwierdzenie odrębności dziejów Rusi Kijowskiej od państwa moskiewskiego. Ludności jej przypisywał pochodzenie słowiańskie, traktował ją jako wschodni odłam Słowian nadwiślańskich - Lachów, Polan, i dlatego uważał, że losy Rusi należy ujmować łącznie z historią Polski a nie Moskwy (Duchiński, 1901, ss. 86-87, 1902, ss. 68, 74 i n.).

Warto zwrócić w tym miejscu uwage na sposób ujmowania kwestii ukraińskiej w piśmiennictwie polskim. Nie tylko Duchiński uważał, ze Ruś Kijowska stanowiła twór zasadniczo odmienny od Rosji. Podobnie tę kwestię postrzegał Joachim Lelewel (Wierzbicki, 1999, s. 158), z mniej zaś znanych twórców Józef Popowski (1893, ss. 33-39), polityk galicyjski.Słowian „przydnieprzańskich i przydniestrzańskich” Duchiński widział więc we wspólnocie ludów indoeuropejskich. Bliżej, jak sądzit, było im do Portugalczyków niż do 
Moskali, Moskalom zaś bliżej do ludów Azji. Panowanie dynastii Rurykowiczów - wspólne dla Rusi i Moskwy - nie doprowadziło do niwelacji różnic, które wypływały "(...) z pochodzenia, z ducha i z charakterów oświaty narodów szczepu indo-germańskiego i turańskiego" (Duchiński, 1901, ss. 122-123, 1902, ss. 273-276). „Żywioł turański”, jak pisał Duchiński w innym miejscu, pochłonął skandynawskich władców: „(..) przesiąkli oni na wskroś barbarzyństwem ludu swego" (1904, s. 10). Dlatego też i chrystianizm Moskale pojmowali inaczej. Myśliciel przekonywat, że bardziej wierzyli oni w panowanie szatana niż Chrystusa i stąd pochodziła ich siła, i "nie rząd to uczynił Moskalami czem są, ale Moskale uczynili rząd swój na wzór swój”, przedkładając wiarę w zło nad wiarę w dobro. Dlatego też pojęcie "moralność” było i jest inaczej rozumiane pośród Moskali niż ludów indoeuropejskich - im kto silniejszy, tym bardziej moralny (Duchiński, 1901, ss. 252-259).

\section{ROLA POLSKI W ŚWIECIE SLOWIAŃSKIM}

Owocem dociekań Franciszka Duchińskiego była, jak już wspomniałam, kontrowersyjna, określana także jako rasistowska, teoria o niesłowiańskim pochodzeniu Rosjan (Moskali) (Czapska, 1939-1946, ss. 441-443; A. F.Grabski, 1983; J. Nowak, 2000; Rudnytski, 1979 1980, ss. 692-694; Górny, 2011). Prawdziwymi i najczystszymi Słowianami byli wedle Duchińskiego Polacy, a dalej Białorusini i Ukraińcy. Za kolebkę Słowiańszczyzny uważał on tereny pomiędzy Wisłą a Dnieprem, gdzie Słowianie osiedlili się przywędrowawszy do Europy z Azji jako ostatni z ludów indoeuropejskich. Następnie znad Wisły rozprzestrzeniali się począwszy od VI w. na kontynencie europejskim. Dlatego też, jak podkreślał, wszystkie dzisiejsze narody słowiańskie mają swą praojczyznę w Polsce (Duchiński, 1901, ss. 92-93, 96-101, 135-139). Ponadto, mimo upadku Rzeczypospolitej jako państwa, Duchiński nadal upatrywał w narodzie polskim siły przywódczej dla Słowiańszczyzny. W pierwszej kolejności za najważniejsze uznawał połączenie "(...) lechickich pokoleń Polski nadwiślańskiej i naddnieprzańskiej" (1901, ss. 138-139 i n.), czyli powrót do stanu pierwotnej jedności. W tym miejscu warto dodać parę słów na temat ukraińskich koncepcji dotyczących etnogenezy Słowian. "Mit początku” Ukrainy zawiera kilka wątków tematycznych, a mianowicie: biblijny jako źródło etnogenezy (pochodzenie od Jafeta), koncepcję Ukrainy jako praojczyzny ludów indoeuropejskich oraz teorię aryjskiego pochodzenia Ukraińców. W pewnym sensie jest więc bardzo bliski koncepcji Duchińskiego. Ponadto, w ukraińskiej wersji dziejów, Ukraina stanowiła przedmurze chrześcijaństwa i broniła świat przed azjatyckim barbarzyństwem. Co jednak ważne, sam naród ukraiński jest traktowany jako wspólnota całkowicie odrębna od Rosjan (sugeruje się ich mieszane pochodzenie rasowe), Ruś Kijowska zaś określana jest mianem państwa ukraińskiego (Rudnytski, 1979-1980, ss. 700-704; Wilson, 2002, ss. 1-39).

Śledzenie dziejów Słowian nadwiślańskich ostatecznie doprowadziło Duchińskiego do wniosku, że byli oni dzięki swej liczebności oraz

(...) zachowaniu w czystości żywiołu narodowego (...) pierwszymi (...) w swoim rodzie. (...) pierwszeństwo tego rodzaju zachowało się zawsze przy nich, ale, nadto zabłysnęli oni sławą w świecie słowiańskim i przez wysoki wyrób oświaty swej słowiańsko-polskiej i powszechnej, europejskiej, to jest tacińskiej; zabłysnęli oni nadto, jeszcze więcej, w olbrzymich walkach moralnych i materialnych, jako obrońce tego świata słowiańskiego przeciwko dwom onego najgroźniejszym i najpotężniejszym wrogom, to jest przeciwko Niemcom i przeciwko Uralczykom; na ostatek, i to najważniejsza - tylko Polacy i Rusini połączeni potrafili zachować rzecz 
najdroższą w życiu narodów i ras, zupełną niepodległość swoją, aż do czasowego upadku pod przemocą sprzymierzonych z sobą Niemców i Moskali (...) (Duchiński, 1901, ss. 137-138).

Fakt, iż Europa i Azja nie stanowiły jedności, a jednocześnie były jednym lądem, wynikał wedle Duchińskiego także z woli boskiej. Z jednej więc strony ludzie zostali zmuszeni do życia w łączności, „(...) do praktykowania cnót chrześcijańskich w robieniu sobie wzajemnych ustępstw", z drugiej zaś wyraźny w sensie geograficznym podział (granice Europy to Morze Bałtyckie i okolice wschodniego brzegu Dniepru) miał ułatwić praktykowanie Bożej nauki najpierw na obszarze o wydzielonym zasięgu, w ten sposób, by grupy ludzkie sobie bliższe łączyły się w pierwszej kolejności. W państwie moskiewskiewskim doszło do wykształcenia się jednorodności społecznej, w polskim do wytworzenia się prowincjonalizmów, które dążąc do jedności w imię wyższej idei, stworzyły odmienną cywilizację.

Połączenie takie zawsze ma na celu wyższą myśl moralną, dla dopełnienia której życie prowincjonalne nie wystarcza, a więc tak utworzone społeczeństwo musi mieć więcej żywiołu moralnego aniżeli społeczeństwo, które powstało jedynie li na prawach pierwotnej plemienności, bo tu nie było wyrobu osobistości, nie było moralnych walk, a więc nie było i ofiary z praw osobistości dla jakiego celu wyższego (Duchiński, 1902, ss. 10-13, 114, cyt. s. 13).

Dlatego też w sensie cywilizacyjnym mieszkańcy Polski stali wyżej niż mieszkańcy Moskwy. Niwelowanie prowincjonalizmów (rozumiane jako dobrowolne zbliżenie na prawach federacji) stanowiło oś całej dotychczasowej historii Polski, i proces ten Duchiński traktował jako nigdy się niekończący. Podobnie postrzegał sytuację innych ludów indoeuropejskich, w Hiszpanii, Francji, Anglii, w Niemczech i Szwajcarii - wszędzie powstawały prowincjonalizmy dyktowane warunkami geograficznymi (różnorodność systemów gór i rzek, charakterystyczna dla Europy) a jednocześnie dochodziło do społecznej adaptacji (Duchiński, 1902, ss. 29-30, 32). W Moskwie natomiast (podobnie jak we wszystkich państwach narodów stepowych) naczelną zasadę zawsze stanowił podbój (Duchiński, 1902, s. 33). Dlatego też nie doszło tam do wykształcenia się narodowości na wzór europejski, przy której powstawaniu konieczna jest wielość indywidualności (Duchiński, 1902, s. 259; Duchiński 1904, ss. 20-24). Podsumowując ten fragment rozważań, autor stwierdzał, że jakkolwiek „(...) wszystkie narody mogą wszędzie mieszkać i okazywać dowody największego swego szczęścia materialnego (...), nie można jednak zaprzeczyć tej prawdzie, że każdy naród, jak i każdy człowiek, jeżeli jest wolny, wybiera ziemię, która najwłaściwszą jest dla jego sposobu życia, dla jego skłonności" (Duchiński, 1902, ss. 26-28). Utrwalony pomiędzy Polską a Moskwą „porządek odwieczny”, wynikający tak z odmienności pochodzenia, jak i warunków geograficznych, a w konsekwencji kultury, został zakłócony przez zaborcze azjatyckie państwo. Uniemożliwiło ono poprzez unicestwienie polskiej państwowości zarówno sobie jak i Polsce realizację (danego przez Boga) „posłannictwa” w sposób niezależny od siebie, niepodległy (Duchiński, 1902, s. 31). Sytuacja polityczna nie przekreśliła jednak przywódczej roli narodu polskiego pośród narodów słowiańskich.

\section{RECEPCJA KONCEPCJI DUCHIŃSKIEGO W POLSCE}

Jakkolwiek Duchiński starał się udowodnić naukowo swe przekonanie o niesłowiańskości Rosjan, to jednak zdawał sobie sprawę, że jego tezy mogą zostać podważone. Tak w istocie się stało. Może dlatego wielokrotnie w swoich pracach zaznaczał, że nawet gdyby 
Moskale Słowianami i indoeuropejczykami byli z pochodzenia, to w sensie mentalnym "z ducha i charakteru cywilizacji” i tak pozostaną im całkowicie obcy. Podobnie, gdyby język rosyjski uznać za słowiański (choć "najnieczyściejszy”, także wedle P. Szafarzyka i A. Mickiewicza), to pozostaną Moskale Słowianami z mowy, a "Uralczykami" w sensie cywilizacyjnym (Duchiński, 1901, ss. 178-179). Wyjaśniał, że przy ocenianiu odmienności narodów

(...) mniej znaczą stopnie ich pokrewieństwa podług krwi, czyli pochodzenia, mniej znaczą stopnie ich pokrewieństwa z mowy uważanej pod względem formy wyrazów czyli słownikarskim, mniej znaczą stopnie ich pokrewieństwa w wielu innych punktach cywilizacji; - mniej to wszystko znaczy - uważmy dobrze - wobec charakterów stosunków historycznych i politycznych (Duchiński, 1902, s. 213).

W przedmowie do zbiorowego wydania pism Duchińskiego Stanisław Grabski, ówczesny bibliotekarz Muzeum Narodowego w Raperswilu, nie przeprowadził zasadniczej krytyki ich treści. Zwrócił uwage, że twórczość i działalność Duchińskiego zyskała poparcie księcia Adama Czartoryskiego (S. Grabski, 1901, ss. XVII-XVII). Grabski nie uważał jednak prac Duchińskiego za spełniające kryteria naukowości. Pisał, że ich autor

(...) naukowej metody badań historycznych nie posiadał, że się nad nią głębiej nie zastanawiał, ani się też o zdobycie jej specjalnie nie starał. (...) Nie istniały więc dlań zdobycze Niehbura i Rankego na polu krytyki i interpretacji źródeł historycznych, Humboldta w zakresie metody badań geograficznych i antropologicznych, Micheleta w kwestii odtwarzania przeszłości (S. Grabski, 1901, s. XXII).

Grabski również odmawiał Duchińskiemu miana prekursora interdyscyplinarnego ujmowania dziejów, jakie przypisywali mu Bronisław Trentowski i Agaton Giller, oraz wskazywał na przewage argumentów z zakresu antropologii biologicznej (fizycznej). Właściwości narodowe bowiem Duchiński objaśniał także poprzez odmienne pochodzenie rasowe ludów (S. Grabski, 1901, ss. XXII-XXIV, XXVIII-XXIX; J. Nowak, 2000, ss. 117-118). Ówczesny raperswilski bibliotekarz podnióst jednakże zasługi Duchińskiego na polu odrodzenia polskiej świadomości narodowej. Przyczyniła się do tego jego walka z ideą panslawizmu, której jądro stanowiła koncepcja zjednoczenia wszystkich narodów słowiańskich pod przywództwem Rosji w oparciu o rzekome „pobratymstwo kulturalne” Słowian. Przywotywał opinie historyka Juliana Bartoszewicza, który pisał, że „pogląd jego [Duchińskiego - K. W.] jest wyjęty z serca narodu i z głowy wszystkich głębszych myślicieli" (S. Grabski, 1901, s. XXX). Wszyscy wyżej wspomniani dostrzegali cywilizacyjne, choć nie określali ich jako rasowe, różnice pomiędzy europejską Polską a azjatycką Rosją, a także odwieczny między nimi antagonizm (Wrzesińska, 2012, ss. 247-303).

W podobnym duchu interpretował spuściznę Duchińskiego Agaton Giller. Jednakże bezkrytycznie odniósł do jego koncepcji, traktując ją jako w pełni uzasadnioną naukowo przyjął tezę o niesłowiańskim pochodzeniu Rosjan i fundamentalnych różnicach pomiędzy rasami turańską i aryjską. Podobnie uczynili polityk galicyjski Franciszek Smolka i gen. Antoni Jeziorański (Karpiński, 1994, ss. 172-173). Giller pisał:

(...) na Wschodzie, na gruncie azjatyckiej kultury, państwo doszedłszy do potęgi olbrzymiej, pochłonęło prawa człowieka i wcieliwszy się w osobę despoty, wstrzymało rozwój i postęp moralny i materialny ludzkości; na Zachodzie, na gruncie europejskiej kultury, prawo jednostki

\section{…..}

5 Byłaby to refleksja zgodna z przemyśleniami A. Mickiewicza na temat Litwinów, których wieszcz traktował jako Słowian. Poczucie słowiańskości ujmował nie jako wynikające ze „związku krwi”, ale z uwarunkowań historyczno-kulturalnych i politycznych (Wierzbicki, 2012, s. 71). 
jest w ciągłej walce z prawem ogółu i powoduje nieustający ruch społeczny i polityczny, rozrost i postęp cywilizacji ku wszechstronnemu pożytkowi cywilizacji (Giller, 1885).

Giller wskazywał na zasługi Duchińskiego w walce z „panmoskwicyzmem, przebranym w szatę słowiańską". Określał Kijowianina (pod takim pseudonimem częstokroć pisywał Duchiński) mianem „znakomitego badacza historycznego i etnografa”, który bez „uprzedzeń ani też ślepej a nieubłaganej nienawiści” przedstawił charakter dwóch krańcowo odmiennych od siebie cywilizacji - azjatyckiej i europejskiej. Giller akceptował również przekonanie Duchińskiego o fałszowaniu historii Rosji przez jej rodzimych historiografów - przede wszystkim chodziło tu o zawłaszczanie dziejów Rusi Kijowskiej (Giller, 1885). Pogląd stwierdzający jedność Rusi z Polską nie był obcy także kontynuatorom twórców romantycznych, do których można zaliczyć historyka i publicystę Stefana Buszczyńskiego. Tu bowiem ujmowano problem rusiński w kategoriach wzbogacającego prowincjonalizmu. Rusinów i Polaków traktowano jako należących do jednego z odłamów Słowiańszczyzny (Polan), czy wręcz jako jeden naród (J. Nowak, 2008b, s. 276). Wspomniany Buszczyński, kontynuując w Europie Zachodniej starania Duchińskiego mające na celu demistyfikację zaborczej polityki Rosji w oparciu o ideę panslawizmu, z przekonaniem powtarzał opinie swego poprzednika, wzbogacając je o własne przemyślenia (Buszczyński, 1884, ss. 3-27; Bezstronny [Buszczyński], 1882).Warto wspomnieć, że w myśli ukraińskiej widoczna jest wybiórcza recepcja poglądów Duchińskiego. Nie zawiera ona wątku polsko-ukraińskiej jedności, powiela natomiast i rozwija interpretację relacji ukraińskorosyjskich, akcentując przede wszystkim różnice między Ukraińcami a Rosjanami. Identyczne są oceny dotyczące polityki Rosji i jej odwiecznie wrogiego stosunku do Europy (Rudnytski, 1979-1980, ss. 699-704).

Komentarzom pełnym aprobaty dla poglądów Duchińskiego towarzyszyła równocześnie ich krytyka. Polskie środowisko naukowe poczęło mu zarzucać dyktowane przesłankami politycznymi antyrosyjskie zaślepienie. Wacław Nałkowski obalał jego tezy w artykule "O geograficznych błędach, na których opierają się historiograficzne poglądy Profesora Duchińskiego" (1881). Podobnie Jan Baudouin de Courtenay odmawiał dorobkowi Duchińskiego miana naukowego, opartego na źródłach, i oceniał jego charakter jako wyłącznie polityczny. Wedle tej oceny, krytykowany autor „poświęcał tendencyjnie prawdę polityce", a jego abstrakcyjne wywody przynosić miały szkody moralne i umysłowe - rozniecały nienawiść między narodami, czyniły między nimi niczym nieuzasadnione podziały (Baudouin de Courtenay, 1886, ss. 5, 30 i n.). Baudouin de Courtenay nie pierwszy podważył metody naukoweDuchińskiego, ale jako jeden z nielicznych zakwestionował pogląd o niezbywalnych różnicach cywilizacji Wschodu i Zachodu, świata „aryjskiego" i „turańskiego", które stanowiły trwałą przeszkodę w ich wzajemnym porozumieniu. Przeprowadził niepozbawiony nuty złośliwości wywód, w którym podważał argumenty Duchińskiego, a myśl przewodnią autora potraktował jako „(...) podyktowaną przez nienawiść plemienną i zarozumiałość narodową" (Baudouin de Courtenay, 1886, s. 7). Ta ocena nie mogła być inna, gdyż Janowi Baudouin de Courtenay jako zdeklarowanemu pacyfiście obce być musiało pojmowanie świata w kategoriach nieustannej walki, różnicowanie podług ras, traktowanie Europy Zachodniej jako przeciwwagi dla ciemnych sit Wschodu, czy wreszcie stereotypowe traktowanie Polski jako przedmurza tejże Europy (Davies, 1992, ss. 87-88). Warto zwrócić uwagę, że dla XIX-wiecznych komentatorów teorii Duchińskiego samo pojęcie "rasa" nie stanowiło problemu, nie rodziło emocji. Fakt ten potwierdza, że ówcześnie nie uznawano go za naganne, stosowano dowolnie i nie przykładano uwagi do ścisłych definicji. 
W latach 80. XX w. krytykę koncepcji Franciszka H. Duchińskiego podjął historyk Andrzej Feliks Grabski, kwestionując, podobnie jak jego poprzednicy, tezę o niesłowiańskości Rosjan, zbudowaną w oparciu o wątpliwej jakości materiał (A. F. Grabski, 1983, ss. 221-278). Novum stanowiło uznanie emigracyjnego działacza za prekursora na gruncie nauki polskiej kierunku rasowo-antropologicznego, w którym „czystość pochodzenia etnicznego" uznana zostaje za podstawowy wyznacznik wspólnoty. Grabski wskazywał przy tym na recepcję poglądów Josepha Arthura de Gobineau na temat nierówności ras ludzkich, co w kontekście analizy tekstów Duchińskiego nie wydaje się w pełni zasadne. Nie popełni się chyba błędu, stwierdzając, że tekst Grabskiego, powstały na początku lat 80. XX w., nosi piętno pewnej ideologizacji. Krótko rzecz ujmując, nie mogli przecież Rosjanie, a przynajmniej rewolucjoniści, chcieć krzywdy Polaków czy Słowian w ogóle. Ci z kolei nie dostrzegali pozytywów płynących z możliwości egzystencji w ramach szeroko pojętej wspólnoty pod egidą Rosji. Grabski zarzucił więc Duchińskiemu niedostrzeganie woli „(...) współpracy sił postępowych i rewolucyjnych Polski i Rosji”, widocznej w okresie międzypowstaniowym i po powstaniu styczniowym (A. F. Grabski, 1983, ss. 276-277). W tym kontekście wyraźne staje się uwikłanie zarówno Duchińskiego jak i Grabskiego w polityczny aspekt sporów pośród Słowian, w walkę pomiędzy cywilizacjami Wschodu i Zachodu.

Interesującą analizę porównawczą poglądów Duchińskiego i francuskiego uczonego Jeana-Louisa A. de Quatrefagesa de Bréau przeprowadził M. Górny (2011, ss. 681-706). Uwzględnit przy tym wyczerpująco europejską recepcję teorii polskiego myśliciela. Wspomniany tekst, jak głosi jego podtytuł, stanowi "przyczynek do historii rasizmu”. Istotnie z perspektywy dzisiejszej wiedzy ta interpretacja wydaje się słuszna. Nie można jednak zapominać, że XIX-wieczne rozważania na temat roli czynnika rasowego w dziejach stanowiły dla ówczesnych uczonych interesujące novum, a przypuszczenia traktowano często jako teorie naukowe. Wypada się zgodzić z H. Arendt, że nie można ich obciążać oskarżeniem o sprzyjanie rasizmowi w obecnym znaczeniu tego słowa (Arendt, 1993, ss. 225-226).

\section{PODSUMOWANIE}

Poglądy Duchińskiego i jego działalność publicystyczna na emigracji we Francji (18601864) wyrastały z atmosfery politycznej tego okresu i miały wpływ na kształtowanie zarówno opinii polskiej jak i francuskiej. Wielka Emigracja w przytłaczającej części prezentowała stanowisko antyrosyjskie - w panslawizmie rosyjskim upatrywała zagrożenia dla Polski i innych narodów słowiańskich. Stąd koncepcja polskocentrycznego slawizmu (Wierzbicki, 1984; A. F. Grabski, 1983, s. 240; J. Nowak, 2008b, ss. 120-122). To właśnie głos Duchińskiego przyczynił się do niechętnego przyjęcia w Europie Zachodniej, przede wszystkim we Francji, koncepcji hegemonii Rosji pośród narodów słowiańskich. Było to niezwykle istotne, ponieważ właśnie w XIX w. kształtowało się w Europie wyobrażenie europejskości i słowiańskości jako cech kulturowo przeciwstawnych, utrwalał się mit o antytezie Europy i Słowiańszczyzny (Bobrownicka, 1995, s. 33 i n.). Jak pisze Maria Bobrownicka, akcentowały ją obydwie strony, choć najbardziej ostro opozycyjność ta, czy wrogość, objawiała się w idei panslawizmu wyrastającej z myśli słowianofilów rosyjskich. Spośród narodów słowiańskich jedynie Polacy nie ulegli mitycznej wizji, która zacierała istotne różnice kulturowe między strefami łacińską i bizantyjską w obrębie Słowiańszczyzny. Natomiast sama 
Europa Zachodnia zafascynowana Rosją, co najmniej od jej zwycięstwa nad Napoleonem, przyjęła ją jako jedynego reprezentanta świata słowiańskiego, partnera politycznego i gospodarczego, siebie zaś zaczęła postrzegać (wedle koncepcji niemieckiego historyka Leopolda Rankego) jako „małżeństwo romańsko-germańskie”, w którym „element słowiański jest (...) intruzem" (Bobrownicka, 1995, s. 42). Panslawizm, przeciw któremu Duchiński protestował za pomocą tezy o niesłowiańskości Rosji, był niebezpieczny nie tylko dla Słowian, mieszkańców Europy Środkowej, ale i dla Europy Zachodniej.

Gdyby odrzucić teorię Duchińskiego, uznając nienaukowość jego argumentacji, pozostanie cały wachlarz wniosków autora na temat azjatyckiej despotii, które nie odbiegały od powszechnych nie tylko w publicystyce polskiej XIX i XX w. opinii, ale także istniejących w polskiej historiografii. Jeśli Duchiński pisał o obcości cywilizacyjnej Rosji wobec świata Zachodu, do którego zaliczał Polskę, o tyranii pochodzenia azjatyckiego miażdżącej wolność i godność jednostki, o zagrożeniu cywilizacji europejskiej przez barbarzyński Wschód, czy wreszcie o misji, jaką miała pełnić Polska na przedmurzu chrześcijaństwa, a także wobec Słowian - nie różnił się w swych poglądach od wielu polskich myślicieli. Przeświadczenie o obcości cywilizacyjnej Rosji wobec Europy oraz azjatyckim charakterze (a więc niekoniecznie pochodzeniu) Rosjan było bowiem głównym rysem ówczesnych rozważań. W tym duchu ujmowali powyższe zagadnienie m.in. Franciszek Ksawery Godebski, Wojciech Jastrzębowski, Bronisław Trentowski, Joachim Lelewel. Wskazywano na proces deslawizacji Rosjan, który w rezultacie uczynił z nich "niepełnych" lub po prostu "fałszywych" Słowian (Wierzbicki, 2012, ss. 72-75). Wielu, na przykład Adam Mickiewicz, choć uznawało słowiańskość wschodniego imperium, podkreślało odmienności na płaszczyźnie idei (systemu wartości, formy rządów) pomiędzy Polską i Europą a Rosją, a w związku z tym wzajemną wrogość (Karpiński, 1994; J. Nowak, 2008a, ss. 41-55; de Lazari, 2006).

Podobne przekonania głosito wielu wybitnych polskich historyków, m.in. Walerian Kalinka, Józef Szujski, Tadeusz Korzon, Władysław Smoleński, Bronisław Dembiński czy Szymon Askenazy (Filipowicz, 2000; Wierzbicki, 2001), nie były więc one zależne od szkoty historycznej. Nie musiały wynikać z zapatrywań politycznych. Wystarczy wspomnieć Henryka Rzewuskiego - wobec Rosji ugodowego i prezentującego antynarodową postawę - który jednak duch europejski i duch azjatycki postrzegał jako dwa przeciwne i zwalczające się żywioły (Rzewuski, 2007, ss. 42-43), czy Romana Dmowskiego, u którego zainicjowanie polityki orientacji na Rosję nie kłóciło się z przekonaniem o azjatyckości tego państwa (Wrzesińska, 2012, ss. 247-271, 284-293). I takie rozumienie problemu okazało się niezwykle trwałe. Uwidoczniło się jaskrawo w działalności Wielkiej Emigracji, a także piśmiennictwie polskim (również prasie partii politycznych) na przełomie XIX i XX W. Konflikt między Polską a Rosją uwieczniony został nie jako lokalny spór, ale jako walka cywilizowanej Europy z barbarzyńskim Wschodem. Nie mieli więc racji Jan Baudouin de Courtenay i Andrzej F. Grabski, pisząc, że argumentacja Duchińskiego mogła przekonać ludzi „,niezbyt krytycznie myślących”, „odznaczających się nieznajomością rzeczy i naiwnością, albo też zatrutych nienawiścią” i przyczyniała się do propagowania „agresywnego nacjonalizmu" oraz pogardy dla narodu rosyjskiego (Baudouin de Courtenay, 1886, s. 7; A. F. Grabski, 1983, s. 277). Przekonanymi o obcości cywilizacyjnej Rosji oraz wynikającej z tego źródła trwałej antynomii pomiędzy nią a światem Zachodu były bowiem elity społeczeństwa polskiego (Karpiński, 1994; A. Nowak, 1998, 1999; Wierzbicki, 1999, ss. $156-$ 162; Bohun, 2006, ss. 203-302). 
Dziś wiadomo, że to nie rasa w sensie fizycznym ma decydujący wpływ na kształtowanie się społeczeństw - usprawiedliwiając nieco Duchińskiego trzeba stwierdzić zważywszy na ówczesny stan wiedzy w tej dziedzinie, że mógł tego nie wiedzieć, albo używać argumentacji rasowej skoro zawodziła inna. Jak pisze Samuel Huntington, „cywilizacja i rasa nie są (...) tożsame. Ludzie tej samej rasy mogą należeć do różnych cywilizacji, cywilizacja z kolei może łączyć różne rasy. (...). Tym, co przede wszystkim odróżnia od siebie wielkie grupy ludzi, są wartości, wierzenia, instytucje i struktury społeczne (...)" (Huntington, 2000, s. 45). Amerykański politolog stawia tezę o wadze tożsamości cywilizacyjnej w kształtowaniu „wzorów spójności, dezintegracji i konfliktu” (Huntington, 2000, s. 14). Ujmuje konflikty światowe poprzez pryzmat "starcia cywilizacji". Pośród ośmiu cywilizacji wymienionych przez Samuela Huntingtona znajdują się również zachodnia i prawosławna. Na płaszczyźnie tożsamości cywilizacyjnej ujęcie cech charakteryzujących te "dwa światy" zarówno u Duchińskiego jak i Huntingtona, a można jeszcze wspomnieć choćby Samuela Pipesa (2007), jest całkowicie zbieżne. Dla Zachodu to m.in. dziedzictwo starożytności (grecka filozofia i racjonalizm, prawo rzymskie, język łaciński, chrześcijaństwo), katolicyzm i protestantyzm, rozdział władzy duchowej i świeckiej, rządy prawa, pluralizm społeczny, gremia przedstawicielskie, indywidualizm. Dla Wschodu istotne wyróżniki zaś stanowią: korzenie bizantyjskie, jarzmo mongolskie, brak styczności ze zjawiskami określającymi tożsamość Zachodu (takimi, jak spuścizna rzymska, feudalizm czy Renesans aż po kształtowanie i wyłonienie się państwa narodowego), despotyzm, eliminacja społecznego i politycznego pluralizmu (Karpiński, 1994, ss. 160-180; Huntington, 2000, ss. 88-93, 199-216; Pipes, 2007, ss. 40-41, 50-55). Podział na Zachód i Wschód podług cywilizacyjnej płaszczyzny był też wyraźnie widoczny w XIX-wiecznych koncepcjach rosyjskich, przede wszystkim u Nikołaja Danilewskiego (A. Nowak, 1998, ss. 4563), a współcześnie występuje m.in. u skrajnych nacjonalistów Aleksieja Dugina, Aleksieja Mitrofanowa, Giennadija Ziuganowa. Celem Rosji staje się walka z „kosmopolitycznym i materialistycznym ładem atlantyckim" (Wilson, 2002, ss. 319-327). Podobnie dwa wieki wcześniej myśliciele rosyjscy ujmowali swój stosunek do Zachodu, widząc w nim twór "zgniły” i „zgrzybiały”, dla którego ratunkiem może być jedynie powiew rosyjskiej świeżości cywilizacyjnej (Walicki, 1973, ss. 141-172, 433-434).

Przyznać można rację Duchińskiemu nie, rzecz jasna, w kwestii źródeł odmienności między cywilizacjami wschodnią i zachodnią, ale w wypunktowaniu istniejących na przestrzeni wieków różnic między nimi w praktyce życia społeczno-politycznego i kulturalnego. To co różni Zachód od wszystkich innych cywilizacji i stanowi jego specyfikę to, powtórze jeszcze raz, chrześcijaństwo, pluralizm, indywidualizm i rządy prawa, a w konsekwencji przestrzeń dla narodzin idei wolności jednostki i demokracji politycznej (Huntington, 2000, s. 479). Dzięki tym cechom narody Europy mogą dyskutować nad swym położeniem, krytykować się wzajemnie, a nawet podważać ramy systemu, w jakim funkcjonują. Nie sposób nie przyznać racji Jerzemu Jedlickiemu, gdy spostrzega, „(...) iż nieustająca przeciwko zasadom i instytucjom rebelia jest sama instytucjonalną zasadą funkcjonowania tej i tylko tej cywilizacji" (Jedlicki, 1991, s. 120). 
Arendt, H. (1993). Korzenie totalitaryzmu (T. 1-2). (D. Grindberg \& M. Szawiel, Tłum.). Warszawa: Niezależna Oficyna Wydawnicza.

Baudouin de Courtenay, J. (1886). Z powodu Jubileuszu Profesora Duchińskiego. Kraków: Uniwersytet Jagielloński.

Bezstronny, S. [Buszczyński, S.]. (1882). Przestroga historii: Chronologiczny rys prześladowania Stowian przez Moskali od dawnych wieków do dni dzisiejszych. Lwów: Księgarnia K. Łukaszewicza.

Bielicki, T., Krupiński, T., \& Strzałko, J. (1987). Historia antropologii w Polsce. Przegląd Antropologiczny, 53(1-2), 3-28.

Bobrownicka, M. (1995). Antyteza słowiańsko-europejska: Z problemów stereotypu. W M. Bobrownicka, Narkotyk mitu: Szkice o świadomości narodowej i kulturowej Stowian zachodnich i południowych (ss. 33-43). Kraków: UNIVERSITAS.

Bohun, M. (2006). Oblicza obsesji - negatywny obraz Rosji w myśli polskiej. W A. de Lazari (Red.), Katalog wzajemnych uprzedzeń Polaków i Rosjan (ss. 203-302). Warszawa: Polski Instytut Spraw Międzynarodowych.

Buszczyński, S. (1884). Stowiańska sprawa. Polska i prawa narodów: Odczyty miane na Uniwersytecie w Bolonii 1884. Kraków: Wydawnictwo Nowej Reformy.

Czapska, M. (1939-1946). Duchiński Franciszek Henryk. W Polski Słownik Biograficzny (T. 5, ss. 441-443). Kraków: PAN-PAU.

Davies, N. (1992). Boże igrzysko: Historia Polski (T. 2). (E. Tabakowska, Tłum.). Kraków: Wydawnictwo Znak.

Davies, N. (2014). Serce Europy: Polska: przeszłość we współczesności. (E. Tabakowska, Tłum.). Kraków: Wydawnictwo Znak.

Duchiński, F. H. (1901). Zasady dziejów Polski i innych krajów słowiańskich i Moskwy. W F. H. Duchiński, Pisma Franciszka Duchińskiego (T. 1). Rapperswyl: Muzeum Narodowe Polskie.

Duchiński, F. H. (1902). Zasady dziejów Polski i innych krajów słowiańskich i Moskwy. W F. H. Duchiński, Pisma Franciszka Duchińskiego (T. 2). Rapperswyl: Muzeum Narodowe Polskie.

Duchiński, F. H. (1904). Pierwotne dzieje Polski. W F. H. Duchiński, Pisma Franciszka Duchińskiego (T. 3). Rapperswyl: Muzeum Narodowe Polskie.

Encyklopedia Powszechna. (1865). (T. 21). Warszawa: Nakład, druk i własność S. Olgerbranda.

Filipowicz, M. (2000). Wobec Rosji: Studia z dziejów historiografii polskiej od końca XIX wieku po // wojne światową. Lublin: Instytut Europy Środkowo-Wschodniej.

Gella, A. (1966). Ewolucjonizm a początki socjologii (L. Gumplowicz, L. F. Ward). Wrocław: Zakład Narodowy im. Ossolińskich.

Giller, A. (1885). O życiu i pracach Franciszka Henryka Duchińskiego Kijowianina. Lwów. Pobrano 25 czerwca 2012, z http://www.ukrstor.com/ukrstor/duchinski_zp.htm

Górny, M. (2011). „Pięć wielkich armii naprzeciw wrogom naszym”: Przyczynek do historii rasizmu. Kwartalnik Historyczny, 118(4), 681-706.

Grabski, A. F. (1983). Na manowcach myśli historycznej. Historiozofia Franciszka H. Duchińskiego. W A. F. Grabski, Perspektywy przeszłości: Studia i szkice historiograficzne (ss. 221-278). Lublin: Wydawnictwo Lubelskie. 
Grabski, S. (1901). Życie i działalność literacka Franciszka Duchińskiego Kijowianina. W F. H. Duchiński, Pisma Franciszka Duchińskiego (T. 1). Rapperswyl: Muzeum Narodowe Polskie.

Gumplowicz, L. (1887). System socjologii. Warszawa: Wydawnictwo Spółki Nakładowej. Huntington, S. (2000) Zderzenie cywilizacji i nowy kształt tadu światowego. (H. Jankowska, Tłum.). Warszawa: Warszawskie Wydawnictwo Literackie MUZA SA.

Jedlicki, J. (1991). Stereotyp Zachodu w Polsce porozbiorowej. W J. Tazbir (Red.), Mity i stereotypy $w$ dziejach Polski (ss. 100-124). Warszawa: Wydawnictwo INTERPRESS.

Karpiński, W. (1994) Polska a Rosja. Warszawa: PWN.

Koneczny, F. (1935). O wielości cywilizacji. Kraków: Gebethner i Wolf.

Krasiński, Z. (1912). O stanowisku Polski z bożych i ludzkich względów. W Z. Krasiński,Pisma (T. 7). Kraków, Warszawa: G. Gebethner i Spółka, Gebethner i Wolff.

Krzemień, S. (1971). Przedmowa. W J. Conrad, Człowiek, rasa, kultura (ss. 7-16). (A. Kreczmar, Tłum.). Warszawa: PWN.

Krzywicki, L. (1969). Kurs systematyczny antropologii: Rasy psychiczne. W L. Krzywicki, Dzieła (T. 7). Warszawa: PWN. (Pierwodruk 1902)

Krzywicki, L.(1969). Ludy: Zarys antropologii etnicznej. W L. Krzywicki, Dzieła (T. 7). Warszawa: PWN. (Pierwodruk 1893)

Lazari de, A. (Red.). (2006). Katalog wzajemnych uprzedzeń Polaków i Rosjan. Warszawa: Polski Instytut Spraw Międzynarodowych.

Le Bon, G. (1999). Psychologia rozwoju narodów. (J. Ochorowicz, Tłum. \& Przedmowa). Nowy Sącz: Wydawnictwo V. I. D. I. (Pierwodruk 1897)

Linde, S. B. (1859). Stownik Języka Polskiego przez M. Samuela Linde (T. 5). Lwów: Zakład Narodowy im. Ossolińskich.

Michalski, M. (2013). Dawni Stowianie w tradycji polskiej pierwszej połowy XIX wieku: W poszukiwaniu tożsamości wspólnotowej. Poznań: Wydawnictwo Poznańskie.

Nowak, A. (1998). Polacy, Rosjanie i biesy: Studia i szkice historyczne z XIX i XX wieku. Kraków: Wydawnictwo ARCANA.

Nowak, A. (1999). Jak rozbić rosyjskie imperium?: Idee polskiej polityki wschodniej (17331921). Kraków: Wydawnictwo ARCANA.

Nowak, J. (2000). Kontrowersje wokół Franciszka H. Duchińskiego, zapomnianego polskiego historyka i etnografa. W A. Judycka \& B. Klimaszewski (Red.), Materiały V Sympozjum Biografistyki Polonijnej, Kraków 22-23 września 2000 (ss. 115-123). Lublin: Wydawnictwo Czelej.

Nowak, J. (2008a). Czy Rosja to prawdziwy naród: Romantyczne spory wokół rosyjskiej idei narodowo-państwowej. Sprawy Narodowościowe. Seria nowa, (33), 41-55.

Nowak, J. (2008b). Duchowe piętno społeczeństw: Złożoność i przeobrażenia polskiej refleksji nad narodem w XIX wieku. Warszawa: SOW.

Opacki, Z. (2000). Turańskość-azjatyckość Rosji w polskiej i rosyjskiej myśli społeczno-politycznej XIX i XX wieku. W M. Bohun \& J. Goćkowski (Red.), Zagadnienie rosyjskie: Myślenie o Rosji: oglądy i obrazy spraw rosyjskich (ss. 239-252). Kraków: Wydawnictwo "Secesja”.

Pawlikowski, M. (1952). Dwa światy. Londyn: Veritas.

Pipes, R. (2007) Rosja carów. (W. Jeżewski, Tłum.). Warszawa: Wydawnictwo MAGNUM.

Popowicz, K. (2009). Lamarkizm społeczny a rasizm i eugenika we Francji. Warszawa: Wydawnictwa Uniwersytetu Warszawskiego. 
Popowski, J. (1893). Narodowość - rasa. Słowiaństwo - panslawizm. Kraków: Skład Główny w Księgarni Spółki Wydawniczej Polskiej.

Rudnytsky, I. L. (1979-1980). Franciszek Duchiński and his impact on Ukrainian political thought. (1979-1980). Harvard Ukrainian Studies, 3/4(2), 690-705. Pobrano 21 stycznia 2015 z www.huri.harvard.edu/images/pdf/hus_volumes/vIII-IV_1979-1980_part2.pdf

Rzewuski, H. (2007). Próbki historyczne: Dzieło pośmiertne hr. Henryka Rzewuskiego. W J. Nowak, R. Owadowska, \& K. Wrzesińska (Red.), Polska refleksja nad Europą: Wybór tekstów (ss. 42-43). Poznań, Warszawa: SOW.

Stownik Jezzyka Polskiego. (1861). (T. 2). Wilno: Maurycy Orgelbrand.

Sobeski, M. (1925). Kwiat złoty: Gobineau redivivus. Poznań: Fiszer i Majewski.

Staszic, S. (1959a). Ród ludzki: Wersja brulionowa po raz pierwszy ogłoszona drukiem według zachowanego rekkopisu (T. 2). (Z. Daszkowski, Oprac.). Warszawa: PWN.

Staszic, S. (1959b). Ród ludzki: Wersja brulionowa po raz pierwszy ogłoszona drukiem według zachowanego rekopisu (T. 3). (Z. Daszkowski, Oprac.). Warszawa: PWN.

Strzelczyk, J. (2003). Paweł Józef Szafarzyk (1795-1861) - człowiek i dzieło. W P.J. Szafarzyk, Słowiańskie starożytności (T. 1-2, 1842-1844). (H. N. Bońkowski, Tłum.). Poznań: Wydawnictwo PTPN.

Szacki, J. (1981). Historia myśli socjologicznej (Cz. 1). Warszawa: PWN.

Szczurkiewicz, T. (1969). Studia socjologiczne. Warszawa: PWN.

Szujski, J. (1867). Rys dziejów piśmiennictwa świata niechrześcijańskiego. Kraków: Drukarnia „Czasu" W. Kirchmayera.

W. B. [Popławski, J. L.]. (1900). Polityka i historia. Przegląd Wszechpolski, (7), 413.

Walicki, A. (1973). Rosyjska filozofia i myśl społeczna od oświecenia do marksizmu. Warszawa: „Wiedza Powszechna”.

Wierzbicki, A. (1984). Wschód - Zachód w koncepcjach dziejów Polski. Warszawa: PIW.

Wierzbicki, A. (1999). Historiografia polska doby romantyzmu. Wrocław: Wydawnictwo Funna.

Wierzbicki, A. (2001). Groźni i wielcy: Polska myśl historyczna XIX i XX wieku wobec rosyjskiej despotii. Warszawa: sic!

Wierzbicki, A. (2009). Europa w polskiej myśli historycznej XIX i XX wieku. Warszawa: Wydawnictwo TRIO.

Wierzbicki, A. (2012). Mitologizacje i demitologizacje "Słowiańszczyzny" w polskiej myśli historycznej XIX wieku. W A. Czyżewski, R. Stobiecki, T. Toborek, \& L. Zaszkliniak (Red.), Mity i stereotypy w dziejach Polski i Ukrainy w XIX i XX wieku (ss. 65-78). Warszawa, Łódź: IPN - Komisja Ścigania Zbrodni przeciwko Narodowi Polskiemu.

Wilson, A. (2002). Ukraińcy. (M. Urbański, Tłum.). Warszawa: Grupa Wydawnicza Bertelsmann Media.

Wrzesińska, K. (2012). Kultura i cywilizacja w myśli Narodowej Demokracji (1893-1918): Między ideą wychowania a polityką. Warszawa: SOW. 